\title{
Tectonic Evolution of the Careón Ophiolite (Northwest Spain): A Remnant of Oceanic Lithosphere in the Variscan Belt
}

\author{
Florentino Díaz García, Ricardo Arenas, ${ }^{1}$ José R. Martínez Catalán, ${ }^{2}$ \\ José González del Tánago, ${ }^{1}$ and Greg R. Dunning ${ }^{3}$ \\ Departamento de Geología, Universidad de Oviedo, 33005 Oviedo, Spain \\ (e-mail: floro@asturias.geol.uniovi.es)
}

\begin{abstract}
A B S T R A C T
Analysis of the Careón Unit in the Ordenes Complex (northwest Iberian Massif) has supplied relevant data concerning the existence of a Paleozoic oceanic lithosphere, probably related to the Rheic realm, and the early subduction-related events that were obscured along much of the Variscan belt by subsequent collision tectonics. The ophiolite consists of serpentinized harzburgite and dunite in the lower section and a crustal section made up of coarse-grained and pegmatitic gabbros. An Early Devonian zircon age (395 $\pm 2 \mathrm{Ma}, \mathrm{U}-\mathrm{Pb})$ was obtained in a leucocratic gabbro. The whole section was intruded by numerous diabasic gabbro dikes. Convergence processes took place shortly afterward, giving rise to a mantle-rooted synthetic thrust system, with some coeval igneous activity. Garnet amphibolite, developed in metamorphic soles, was found discontinuously attached to the thrust fault. The soles graded downward to epidote-amphibolite facies metabasite and were partially retrogressed to greenschist facies conditions. Thermobarometric estimations carried out at a metamorphic sole $\left(T \approx 650^{\circ} \mathrm{C} ; P \approx 11.5 \mathrm{kbar}\right)$ suggested that imbrications developed in a subduction setting, and regional geology places this subduction in the context of an early Variscan accretionary wedge. Subduction and imbrication of oceanic lithosphere was followed by underthrusting of the Gondwana continental margin.
\end{abstract}

\section{Introduction}

To unravel the geological history of an oceanic remnant in an orogenic belt is key to a better understanding of the complete evolution of that belt. Achieving this goal is made much more difficult in older orogens such as the Variscan belt in Europe. Classically, and in contrast to Alpine-type orogens, the Variscan belt was considered to be almost devoid of remnants of oceanic crust. This has led some authors to put forward strike-slip or "ensialic" models involving mantle plume processes (Van Calsteren et al. 1979). More recently, oceanic relicts have been identified (Arenas et al. 1986; Arenas 1988), and paleomagnetic data now support the geological evidence of wide Paleozoic oceans (Bon-

\footnotetext{
Manuscript received September 29, 1998; accepted June 1, 1999.

${ }^{1}$ Departamento de Petrología y Geoquímica, Universidad Complutense, 28040 Madrid, Spain.

${ }^{2}$ Departamento de Geología, Universidad de Salamanca, 37008 Salamanca, Spain.

${ }^{3}$ Department of Earth Sciences, Memorial University of Newfoundland, St. John's, Newfoundland A1B 3X5, Canada.
}

hommet and Perroud 1986), while tectonic studies characterize the Variscan belt as a collisional orogen. Inside this belt, the ophiolites appear to have been squeezed among continental or arc-derived crustal fragments, so that the sutures appear as discontinuous belts of low- to high-grade mafic and ultramafic rocks (Martínez Catalán 1990; Matte $1991)$.

In this article we describe the Careón Unit, which crops out in the northwest part of the Iberian Peninsula and represents a suture of the Variscan belt (Martínez Catalán et al. 1997). The unit has been affected by extensional detachments and crossfolding, but detailed field mapping, combined with structural and metamorphic analysis and isotopic data, allow us to characterize its tectonothermal evolution.

\section{Allochthonous Complexes and Ophiolitic Units in Northwest Spain}

Northwest Iberia and the Armorican Massif are linked across the Bay of Biscay, outlining the ar- 
cuate Variscan belt (the Ibero-Armorican Arc) formed by collision between Laurentia and Gondwana (Lefort 1989; Martínez Catalán et al. 1997). The Variscan belt of northwest Iberia (fig. 1) has two main domains, whose pronounced lithological and structural differences have been summarized in figure 2. The lower domain is the relative autochthon and represents a stable marginal platform of Gondwana during the lower Paleozoic. It was deformed during the Upper Devonian and Carboniferous. The upper domain is presently exposed within structural synforms as allochthonous complexes in northwest Spain and northern Portugal. The complexes, three of which occur in northwest Spain, consist of allochthonous units of diverse provenance and different tectonothermal histories but which can be followed from one complex to another. Three groups of allochthonous units have been distinguished in the complexes (Arenas et al. 1995). The three are widely exposed in the Ordenes Complex and, from bottom to top, are the basal, ophiolitic, and upper groups of units (figs. 1, 2).

The contacts between basal, ophiolitic, and upper units traditionally have been interpreted as thrust faults responsible for the stacking of the tectonic units, or terranes, during collision. However, the existence of sudden changes from lower (above) to higher (below) metamorphic grade across ductile shear zones, the downward truncation of footwall units in the transport direction, and the extremely thin lenticular shape of some tectonic units, often dismembered, led us to interpret most of the tectonic contacts as ductile extensional detachments. According to structural and isotopic data, some of them developed during convergence, allowing unroofing of the ophiolitic and high-pressure $(H P)$ basal units (Martínez Catalán et al. 1996; Díaz García et al. 1999).

Several incomplete ophiolitic units crop out discontinuously in the complexes, occupying an intermediate structural position among the allochthonous units. They can be grouped into two sets and are assigned local names. The lower ophiolitic units are essentially made up of low-grade metabasites (derived from basic volcanic and plutonic rocks), metapelites, and felsic meta-igneous rocks. Lenses of serpentinite are also found. In the Spanish complexes, two allochthonous units belong to this group. The Moeche Unit, in the Cabo Ortegal Complex (figs. 1, 2), is a tectonically dismembered and imbricated unit, in which Arenas (1988) recognized the different parts of a complete ophiolite, showing olivine-tholeiitic geochemical affinities. It is composed of metabasalt, broken pillow-breccia, and hyaloclastite, metadiabase, metagabbro, and meta- plagiogranite, as well as tectonic lenses of highly serpentinized ultramafic rocks. The greenschists facies foliation has been dated by the ${ }^{40} \mathrm{Ar} /{ }^{39} \mathrm{Ar}$ method (whole rock in phyllite) at $364.4 \pm 0.7 \mathrm{Ma}$ (Dallmeyer et al. 1997; considered to represent the end of foliation development due to the low temperature of recrystallization). The Vila de Cruces Unit crops out in the southeast of the Ordenes Complex (figs. 1, 3). With lithologies similar to those of Moeche, mylonitization is stronger and no plutonic or volcanic structures are recognized. Mesozonal relics are preserved locally, indicating that a previous amphibolite facies metamorphism affected parts, but not all, of the unit, because most of the metasedimentary rocks never reached medium-grade conditions. Epizonal and mesozonal rocks were imbricated during the low-grade mylonitization event. The greenschist facies mylonitic foliation has been dated at $366.8 \pm 0.4 \mathrm{Ma}$ (Dallmeyer et al. $1997 ;{ }^{40} \mathrm{Ar} /{ }^{39} \mathrm{Ar}$, muscovite concentrate in phyllite).

On top of these essentially low-grade units, an upper set of higher-grade ophiolitic units is represented by the Purrido Unit in Cabo Ortegal and the Bazar and Careón Units in the Ordenes Complex (figs. 1, 2, 3). They are often less deformed, and consist of gabbro, metagabbro, amphibolite, and ultramafic rocks. Neither volcanic nor metasedimentary rocks have been identified in these units. The Purrido Unit (south and west of Cabo Ortegal Complex) consists of medium-grained amphibolite, which locally preserves a granoblastic texture indicative of a gabbroic origin, with E-MORB affinities (Arenas 1988). The unit underwent amphibolite facies metamorphism, dated around $390 \mathrm{Ma}$ (Peucat et al. 1990, ${ }^{40} \mathrm{Ar} /{ }^{39} \mathrm{Ar}$, two hornblende concentrates). The Bazar Unit (west of Ordenes Complex) represents the lower part of an ophiolitic sequence composed of serpentinized dunite and isotropic gabbro with minor intrusions of pegmatitic gabbro. The isotropic gabbro rocks exhibit a tholeiitic character, with flat patterns in the REE diagram normalized to chondrite, and show similarities to volcanic arc basalts, based on positive anomalies in light lithophile elements and marked negative Nb anomaly (Díaz García 1990). The Careón Unit, outcropping to the southeast of the Ordenes Complex, is the subject of this study.

\section{The Careón Unit}

This unit belongs to the upper ophiolitic set and is rather well exposed in the Sierra del Careón. It is made up of three tectonically imbricate sheets (figs. $3,4)$ whose main characteristics are summarized 


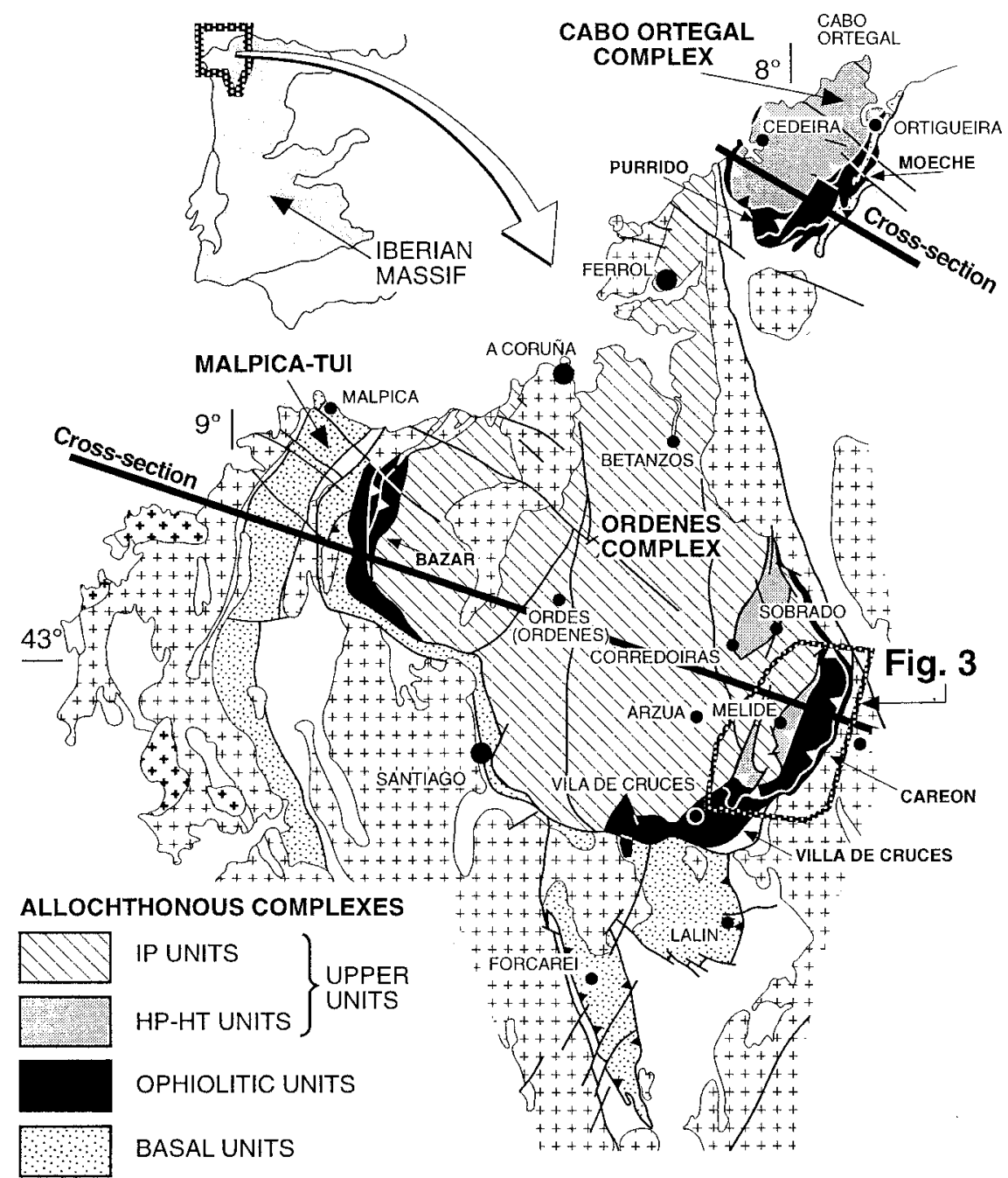

RELATIVE AUTOCHTHON

SCHISTOSE DOMAIN AND CENTRAL IBERIAN ZONE
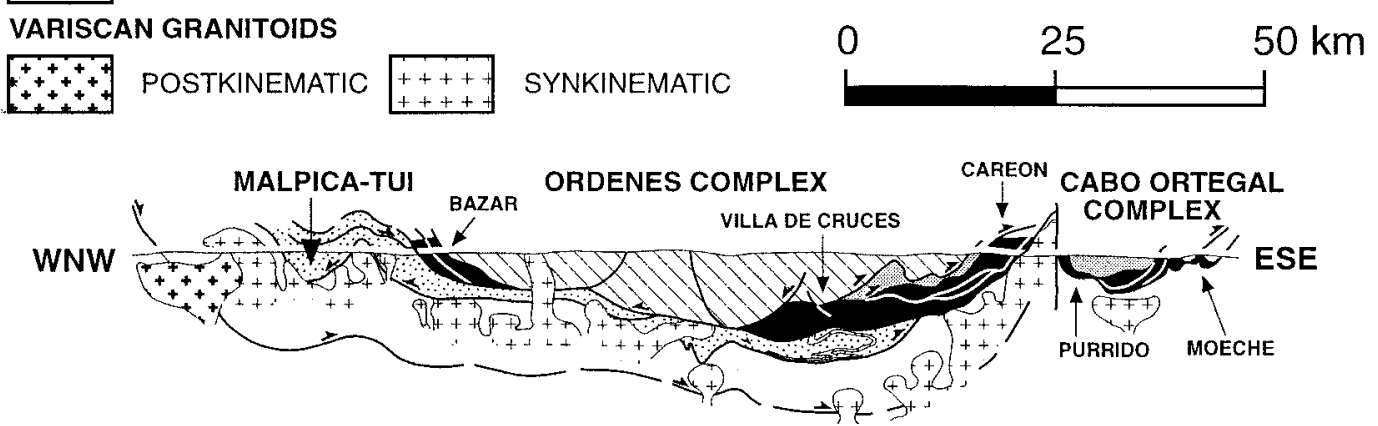

Figure 1. Geological sketch-map and composite cross section of the allochthonous complexes of northwest Spain, showing their main units.

in figure 5. The lower Orosa sheet is made up of a thin, discontinuous, basal sheet of serpentinite and up to $400 \mathrm{~m}$ of amphibolite of gabbroic origin. The Careón sheet, in the middle, shows a sequence composed of $500 \mathrm{~m}$ of ultramafic rocks and $600 \mathrm{~m}$ of metagabbro. The transition between harzburgite and gabbro (considered as the paleo-Moho in the sense of Nicolas 1989) is abrupt and occurs along 


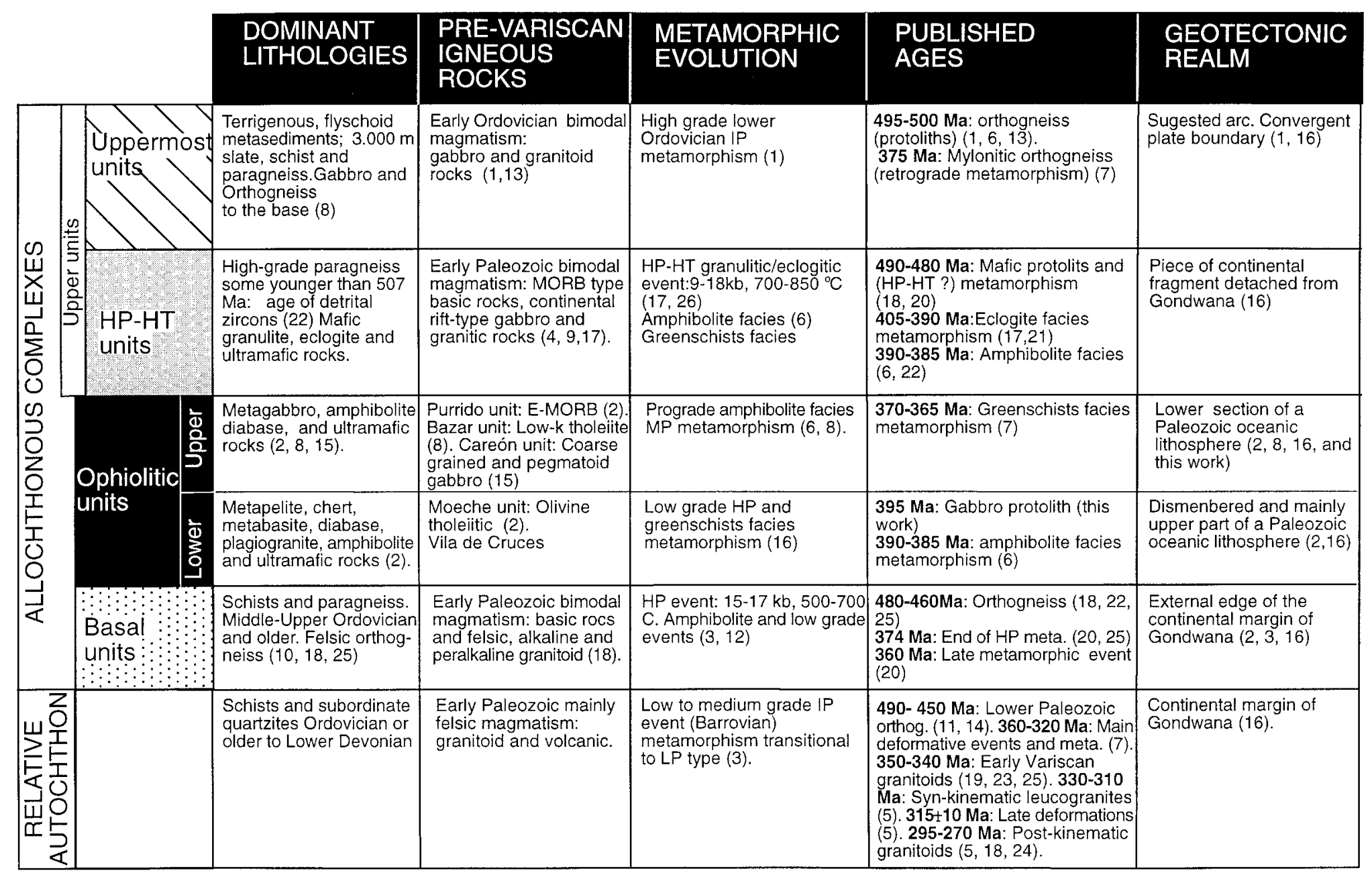

Figure 2. Summary of geological information for the different allochthonous units and the underlying parautochthon domain. Patterns in the left column correspond to those in figure 1. References: 1, Abati et al. 1999; 2, Arenas et al. 1986; 3, Arenas et al. 1995; 4, Bernard Griffiths et al. 1985; 5, Capdevila and Vialette 1970; 6, Dallmeyer et al. 1991; 7, Dallmeyer et al. 1997; 8, Díaz García 1990; 9, Galán and Marcos 1997; 10, García Garzón et al. 1981; 11, Gebauer 1993; 12, Gil Ibarguchi 1995; 13, Kuijper 1979; 14, Lancelot et al. 1985; 15, Martínez Catalán et al. 1984; 16, Martínez Catalán et al. 1996; 17, Peucat et al. 1990; 18, Priem et al. 1970, 19, Priem and Den Tex 1984; 20, Santos Zalduegui et al. 1995; 21, Santos Zalduegui et al. 1996; 22, Schäfer et al. 1993; 23, Serrano Pinto et al. 1987; 24, Suárez et al. 1978; 25, Van Calsteren et al. 1979; 26, Vogel 1967. 
a surface dipping $40^{\circ}$ westward, without significant deformation and mostly parallel to the foliation of mafic and ultramafic rocks and to the basal thrust (figs. 6, 7). In detail, this mafic-ultramafic boundary is intruded by numerous gabbroic and diabase dikes. The Vilouriz sheet occupies the upper structural position of the pile and consists of various levels of ultramafic rocks tectonically imbricated with sheared amphibolite and metagabbroic rocks.

Ultramafic Rocks. Ultramafic rocks are characterized by a high degree of serpentinization, but in scarcely foliated and little serpentinized rocks, a harzburgitic composition can be inferred: olivine, orthopyroxene, tremolitic amphibole, chlorite, brown spinel, and magnetite, with amphibole and chlorite being retrograde products after orthopyroxene. In some localities, these rocks alternate with several-centimeters-thick layers of dunite or transitional zones of harzburgite-dunite, showing coarse-grained porphyroclastic and mosaic textures.

Extensive serpentinization hampers the systematic analysis of high-temperature foliation, locally marked by stringers of Cr-spinels; but the development of peridotite mylonites can be observed at the base of the Careón and Vilouriz sheets. The foliation dips to the west more steeply than the harzburgite-dunite compositional banding (fig. 7). It is characterized by the dimensional orientation of porphyroclastic olivine and orthopyroxene. The orthopyroxene develops kink-type folds, and scarce recrystallization along intragranular fractures is present. The olivine reveals a richer microstructural sequence, ranging from porphyroclasts with the formation of new grains at the edges to those that have completely recrystallized, forming elongate aggregates. Close to the basal thrust, a discontinuous light-dark banding, several centimeters thick, has developed locally as a result of the different degree of reduction in olivine grain size through dynamic recrystallization and the subsequent replacement of the grains by serpentine. The lower $40 \mathrm{~m}$ of the ultramafic section is composed of serpentinite mylonites, which reveal a welldefined mineral foliation and lineation in which olivine and orthopyroxene have been totally replaced by serpentine, chlorite, and amphibole (actinolite-tremolite type). These mylonites have developed microstructures similar to S-C mylonites in which the dominant foliation is formed by C-planes marked by magnetite, ilmenite, and serpentine, between which the S-planes are formed by the dimensional orientation of relic fine-grained olivine, serpentine, and chlorite (Norrell et al. 1989).
A great profusion of more widely spaced C'-planes is also seen, displacing the previous surfaces.

Metagabbroic Rocks. The gabbroic section consists of a complex network formed by multiple intrusions of gabbroic rocks, wehrlite and wehrlitegabbro transitional lithologies, and diabasic to pegmatitic dikes.

Gabbroic rocks outside the ductile shear zones remain mostly undeformed and retain their igneous texture. The most common type is medium- to coarse-grained isotropic metagabbro, commonly intruded by pegmatitic and diabase dikes. A few whole-rock analyses of pegmatitic gabbros for major elements fall indistinctly in the fields of calcalkaline and MORB basalts (Martínez Catalán et al. 1984).

Locally, metagabbro displays a banded appearance characterized by dark green layers (which probably represent wehrlite), alternating with 1050-cm-thick leucocratic gabbro layers. The original mineralogy, which has been well preserved locally, consists of plagioclase, clinopyroxene, hornblende, and ilmenite. Often, however, it appears completely replaced by a mineral association of hornblende, epidote, plagioclase, ilmenite, and titanite. Transformation took place through the development of extensive secondary fibrous, light green amphibole, pseudomorphous after pyroxene, the complete replacement of plagioclase by fine intergrowths of albite-epidote or epidote, and the development of coronitic reaction rims, mainly at the clinopyroxene-plagioclase interfaces but more noticeably at the olivine-plagioclase contacts, in the scarce olivine gabbronorite. This near complete replacement of the original mineralogy attests to intense hydrothermal metamorphism of the gabbroic section.

Amphibolite. Transformation of gabbroic rocks to well-foliated amphibolite is complete in the lower Orosa sheet, where garnetiferous amphibolite occurs discontinuously in the upper part and grades downward to well-foliated epidote-amphibolite facies metabasic rocks having fine-grained nematoblastic textures. In the overlying Careón and Vilouriz sheets, garnetiferous amphibolite appear attached to the allochthonous ultramafic rocks showing granonematoblastic textures, with a foliation defined by plagioclase ribbons and preferred orientation of amphibole, both manifesting intensive dynamic recrystallization. The garnet usually exhibits numerous aligned inclusions of rutile, ilmenite, plagioclase, and amphibole, often continuous with the external foliation observed in the matrix, which is deflected around the garnet porphyroblasts, indicating its synkinematic 


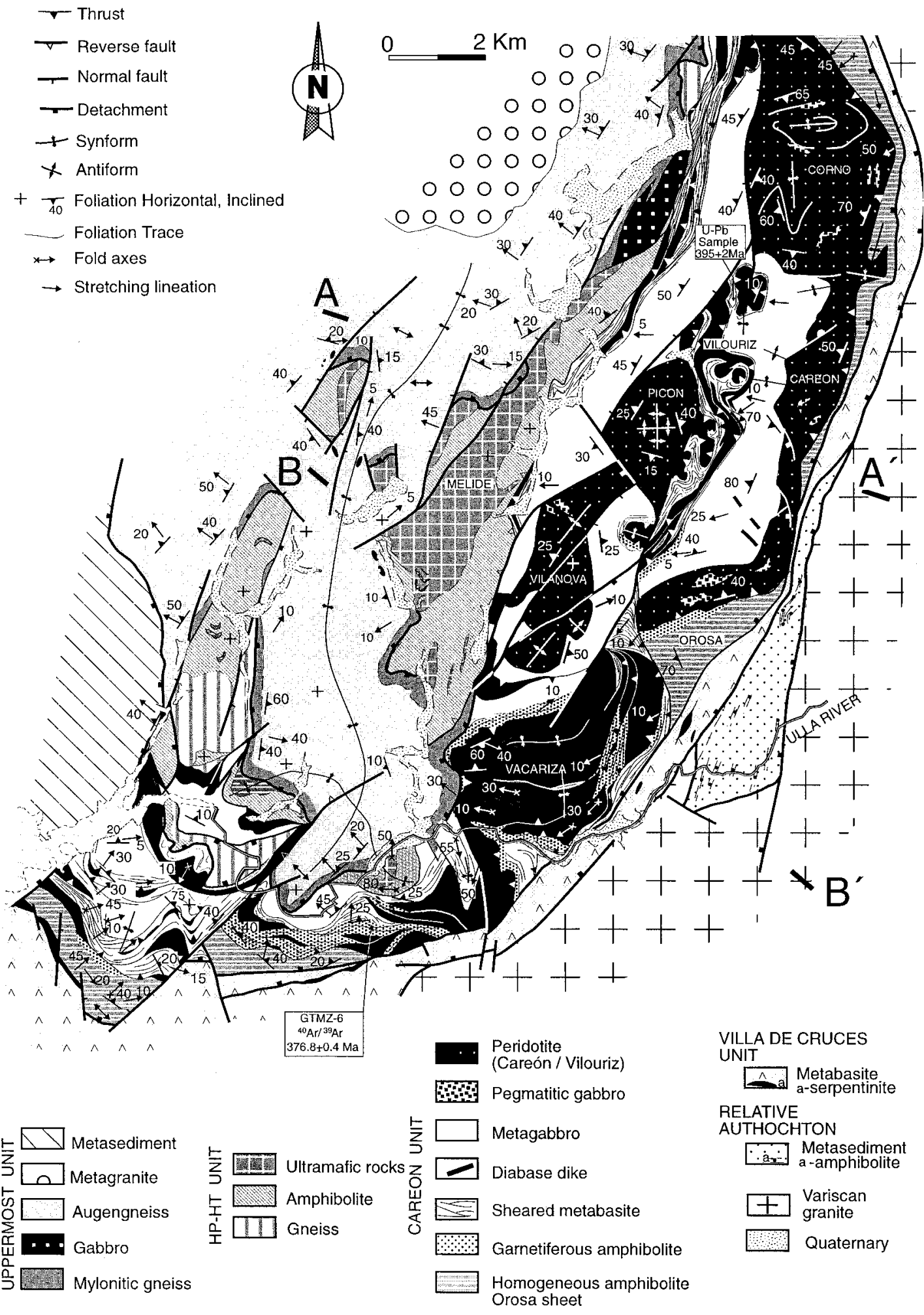

Figure 3. Geological map of the Careón Unit. The sample localities for the U-Pb zircon dating (this work) and the ${ }^{40} \mathrm{Ar} /{ }^{39} \mathrm{Ar}$ hornblende concentrate analysis (Dallmeyer et al. 1997) are shown. 

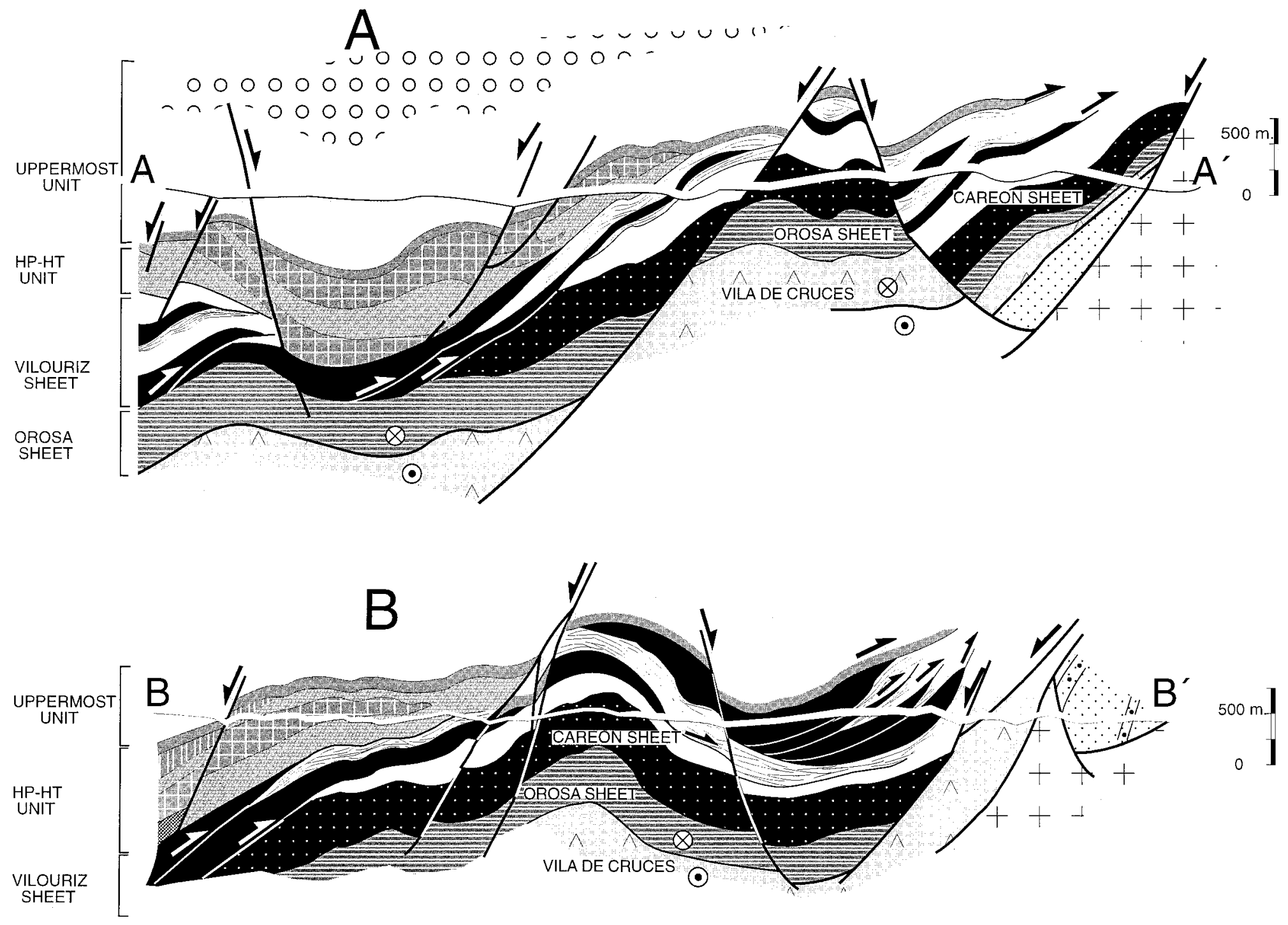

Figure 4. Cross sections $(A$ and $B)$ of the Careón ophiolitic unit (for location, see fig. 3) 


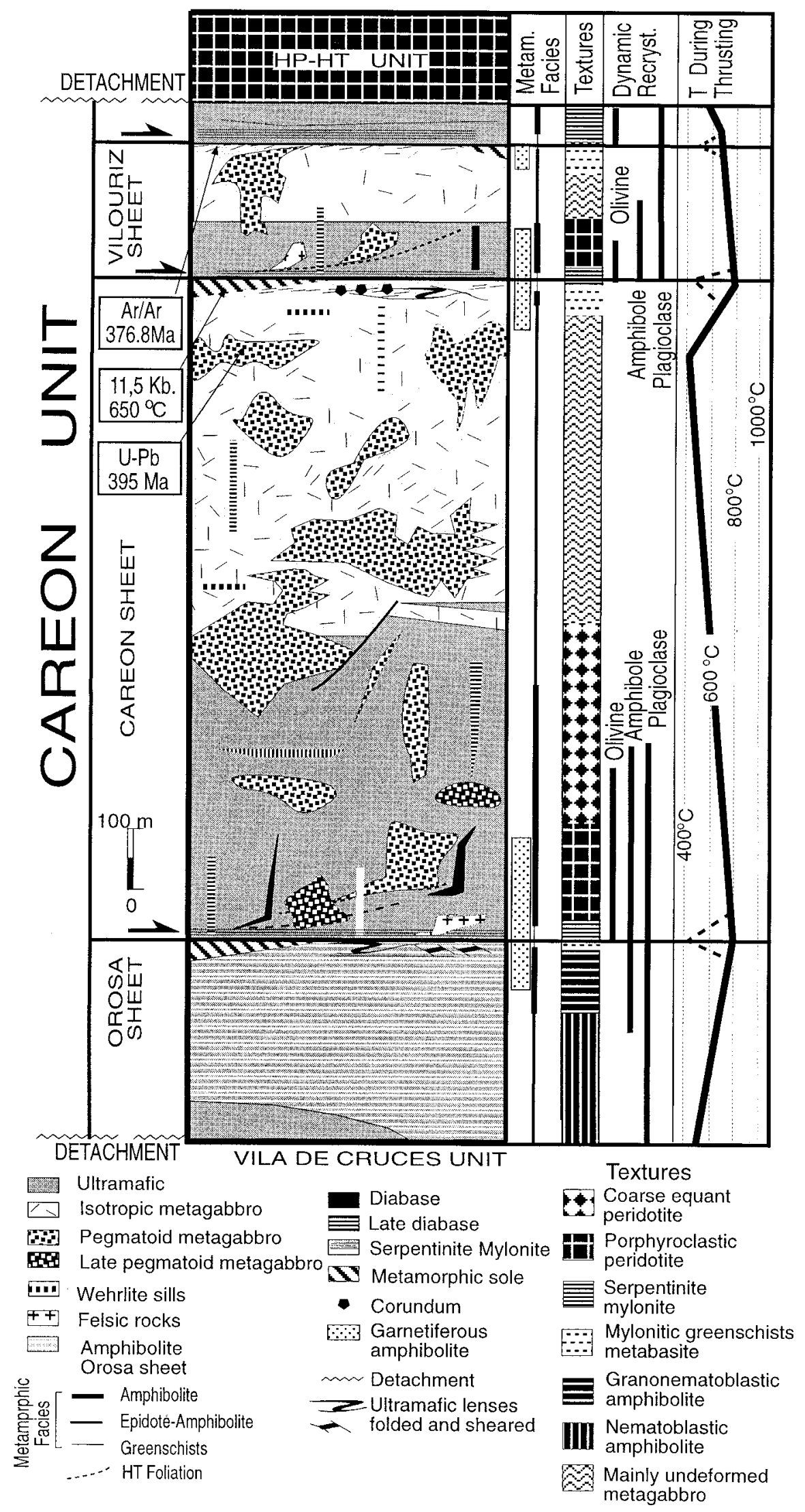

Figure 5. Synthetic log of the Careón ophiolitic unit showing the main lithologies, distribution of metamorphic facies, textures, levels where dynamic recrystallization of main components have been observed, and the sawtoothshaped thermal gradient developed during the earliest (solid line) and final (dashed lines) stages of thrusting. 


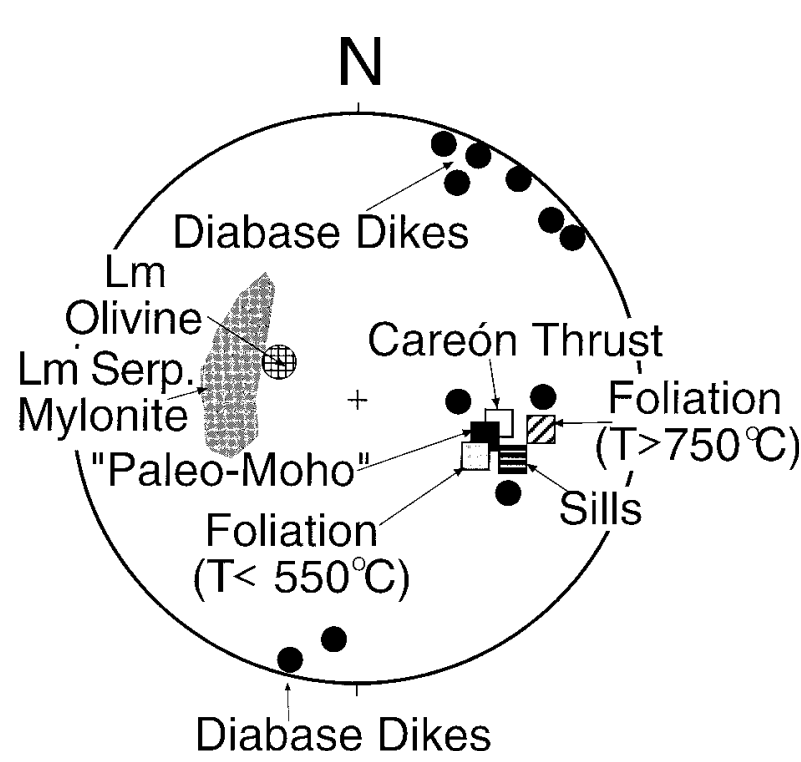

Figure 6. Unrestored stereographic projection (lower hemisphere) of the main structural elements of the Careón sheet at the Careón hill (fig. 3) where the paleo-Moho surface (inferred to be ultramafic-gabbro contact) is considered to be tilted $40^{\circ}$ from its original subhorizontal attitude.

growth. Inside each of the sheets, the garnetiferous amphibolite gives way with increasing depth to epidote-amphibolite facies metabasic rocks. They show porphyroclastic hornblende broken by abundant intragranular fractures where fine-grained amphibole has grown. The plagioclase was transformed into an aggregate of albite and epidote, which underwent deformation accompanied by dynamic recrystallization, giving rise to elongated ribbons. The amphibole of the matrix shows a prismatic habit with a clearly defined dimensional orientation.

Corundum-bearing metabasic rocks occur in a thin band $(3 \times 100 \mathrm{~m})$ immediately beneath the ultramafic rocks of the Vilouriz sheet. The corundum porphyroclasts do not have inclusions, appear surrounded by the greenschist facies foliation of the metabasic rocks, and show rims of fibrous amphibole or are completely replaced by this mineral. The preservation of a high-temperature mineral such as corundum in amphibole-rich metabasic rocks attests to an intense dynamothermal metamorphism (sanidinite facies of Yardley 1989) close to the overlying ultramafic sheet.

The inverted arrangement of metamorphic facies in the upper parts of the sheets is similar to that described in some thrust-related metamorphic soles (Jamieson 1986). Moreover, retrogressive greenschist facies metamorphism is widespread throughout the Careón Unit and is especially concentrated close to the thrust surfaces. It develops serpentinite mylonites in the hanging walls and well-foliated metabasic rocks with fine-grained nematoblastic textures and pervasive shear bands in the footwalls.

Dikes and Sills. A number of meter-size tabular bodies, mainly basic, were intruded roughly parallel and perpendicular to the isotropic gabbroultramafic rock interface (fig. 6). Considering their mineral associations, dike and sill intrusion must have taken place during cooling of the host rock. Dikes and segregations of pegmatitic gabbro that crosscut the gabbroic sills are very common. Some of them exhibit chilled margins where microdiabasic textures developed. In the ultramafic rocks of the Careón sheet (fig. 3), undeformed pegmatitic dikes with dark green and brown hornblende occur; a number of these have been transformed into foliated garnetiferous dark amphibolite, with the foliation defined by brown amphibole and with abundant evidence of plastic deformation in the amphibole and plagioclase. Diabase dikes intruded in the ultramafic rocks contain mineral assemblages equilibrated in greenschist facies; however, some equilibrated in amphibolite facies, with hightemperature mineral associations such as brown amphibole and rutile.

Scarce layers of granitic rocks several meters thick and oriented parallel to the foliation, composed of plagioclase, K-feldspar, quartz, biotite, and variable amounts of amphibole, have been observed in the ultramafic rocks close to the thrust faults (fig. 5) and, very sporadically, in the gabbroic section. These rocks, variably rich in K-feldspar, do not preserve igneous textures but, rather, exhibit a well-developed foliation.

Age of the Ophiolite. One sample of an almost undeformed leucogabbro, located at the top of the Careón sheet (lat $42^{\circ} 57^{\prime} 55^{\prime \prime} \mathrm{N}$ and long $7^{\circ} 57^{\prime} 40^{\prime \prime} \mathrm{W}$; fig. 3), was selected for U-Pb geochronology in order to establish the age of the ophiolitic magmatism. The leucogabbro was composed of sodic plagioclase, epidote, hornblende-actinolite amphibole, ilmenite, titanite, and some quartz. Three fractions of clean and idiomorphic magmatic zircons were separated and analyzed (table 1; fig. 8). All the steps of the U-Pb method were carried out in the Department of Earth Sciences of the Memorial University of Newfoundland, Canada. The laboratory procedures resemble, in general terms, those described by Dubé et al. (1996). Uncertainties on ages and isotopic ratios are reported at $2 \sigma$, considering the propagation of errors from the measurements 

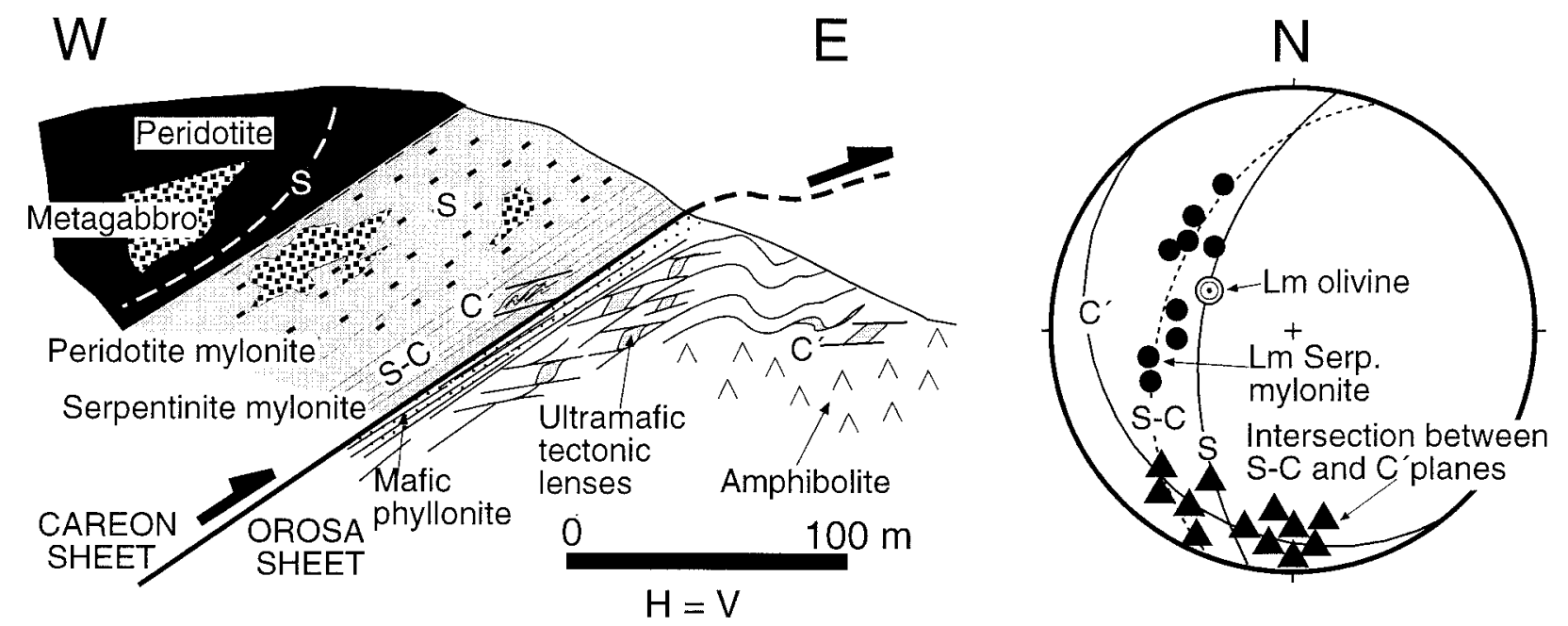

Figure 7. Detailed cross section of the Careón sheet showing the textural variations and the attitude of thrustrelated structures. Stereographic projection (lower hemisphere) shows the attitude of mineral lineation in peridotite and serpentinite mylonite; mean S, C, and $\mathrm{C}^{\prime}$ surfaces; and intersection among these surfaces.

by mass spectrometry, the isotopic fractionation, the lead and uranium blanks $(2-12 \mathrm{pg} \mathrm{Pb}, 2 \mathrm{pg} \mathrm{U})$, and the uncertainty on the isotopic composition of initial common lead, according to the model of Stacey and Kramers (1975). The above calculations on uncertainties were made using an unpublished program of the Royal Ontario Museum, Canada, and the errors of ages are reported at the 95\% confidence level.

The three fractions of zircons gave an almost concordant age of $395 \pm 2 \mathrm{Ma}$ (fig. 8). This age is considered as magmatic and reveals the crystallization age of the leucogabbro. The age obtained represents an important evidence for the generation of oceanic crust and sea-floor spreading in the oceanic realm close to the northern or northwestern margin of Gondwana by Early Devonian time.

Age of Metamorphism and PT Constraints. A hornblende concentrate from the Vilouriz sheet was dated by the ${ }^{40} \mathrm{Ar} /{ }^{39} \mathrm{Ar}$ method (Dallmeyer et al. 1997; see location on fig. 3). The sample is a medium-grained, well-foliated amphibolite consisting of green amphibole (tschermakite to pargasitic hornblende), subidiomorphic garnet, plagioclase, quartz, and minor epidote-clinozoisite, ilmenite, and sphene. The main assemblage is considered to have crystallized at the metamorphic thermal peak. A plateau isotopic correlation age of $376.8 \pm 0.4 \mathrm{Ma}$ represents a cooling age following the amphibolite facies metamorphism. This is slightly younger than 390-380 Ma reported from amphibolite facies metamorphism in equivalent ophiolitic units in Cabo Ortegal (Peucat et al. 1990) and the Portuguese complexes (Dallmeyer et al. 1991).

In order to assess the $P T$ (pressure/temperature) conditions attained by the Careón Unit during the prograde metamorphism, three samples of garnetbearing amphibolite from the metamorphic sole at the top of the Careón sheet were analyzed. To minimize reequilibration caused by retrogressive diffusion during cooling (infinite reservoir concept of Spear [1991]), all the selected amphibolite samples have minor idiomorphic or subidiomorphic garnet distributed in a matrix composed predominantly of green hornblende, plagioclase, and ilmenite. This mineral assemblage is considered to represent peak metamorphic conditions.

Detailed analyses were performed for all the minerals, paying special attention to the microinclusions in the garnet and the development of compositional zoning. Representative chemical analyses of garnet, hornblende, and plagioclase are included in table 2.

Common end-members were calculated in garnets using $\mathrm{Fe}^{2+} / \mathrm{Fe}^{3+}$ ratios estimated by a chargebalance method based on a stoichiometric sum of cations. The garnets in the amphibolite are almandine rich (maximum $59.37 \mathrm{~mol} \%$ ), with low to medium contents in spessartine (maximum 7.85 $\mathrm{mol} \%$ ) and pyrope (maximum $11.48 \mathrm{~mol} \%$ ) endmembers and high contents in grossular component (maximum $27.82 \mathrm{~mol} \%$ ). All the investigated garnets show smooth compositional zoning, with the typical characteristics of a continuous and pro- 
Table 1. U-Pb Data from 94GD10

\begin{tabular}{|c|c|c|c|c|c|c|c|c|c|c|c|c|c|c|c|}
\hline \multirow[b]{2}{*}{ Fraction } & \multirow[b]{2}{*}{$\begin{array}{l}\text { Weight } \\
\text { (mg) }\end{array}$} & \multicolumn{2}{|c|}{$\begin{array}{l}\text { Concen- } \\
\text { tration }\end{array}$} & \multicolumn{2}{|c|}{ Measured } & \multicolumn{7}{|c|}{ Corrected Atomic Ratios } & \multicolumn{3}{|c|}{ Age (Ma) } \\
\hline & & $\begin{array}{c}\mathrm{U} \\
(\mathrm{ppm})\end{array}$ & $\begin{array}{l}\mathrm{Pb} \\
\mathrm{rad}\end{array}$ & $\begin{array}{l}\text { common } \\
\mathrm{Pb}(\mathrm{pg})\end{array}$ & $\frac{206 \mathrm{~Pb}}{204 \mathrm{~Pb}}$ & $\frac{208 \mathrm{~Pb}}{206 \mathrm{~Pb}}$ & $\frac{206 \mathrm{~Pb}}{238 \mathrm{U}}$ & \pm & $\frac{207 \mathrm{~Pb}}{235 \mathrm{U}}$ & \pm & $\frac{207 \mathrm{~Pb}}{206 \mathrm{~Pb}}$ & \pm & $\frac{206 \mathrm{~Pb}}{238 \mathrm{U}}$ & $\frac{207 \mathrm{~Pb}}{235 \mathrm{U}}$ & $\frac{207 \mathrm{~Pb}}{206 \mathrm{~Pb}}$ \\
\hline Z1 clr euh $\operatorname{lrg}$ abr & .553 & 115 & 7.6 & 54 & 4719 & .1541 & .06316 & 26 & .4755 & 22 & .05460 & 8 & 395 & 395 & 396 \\
\hline Z2 clr lrg euh abr & .580 & 118 & 7.7 & 63 & 4273 & .1485 & .06270 & 28 & .4718 & 22 & .05457 & 10 & 392 & 392 & 394 \\
\hline Z3 clr euh abr & .453 & 90 & 5.8 & 36 & 4420 & .1469 & .06250 & 20 & .4703 & 16 & .05458 & 8 & 391 & 391 & 395 \\
\hline
\end{tabular}

grade growth zoning (Frost and Tracy 1991). From core to rim, $\mathrm{X}_{\mathrm{Mg}}$ and $\mathrm{X}_{\mathrm{Fe}}$ exhibit very slight increments, $\mathrm{X}_{\mathrm{Ca}}$ and the $\mathrm{Fe} /(\mathrm{Fe}+\mathrm{Mg})$ ratio remain almost constant, and the $\mathrm{X}_{\mathrm{Mn}}$ shows a significant decrease (fig. 9).

The structural formulae for amphibole were calculated by assuming total cations equal to 13 (except Ca, Na, and K; Leake 1978; Spear and Kimball 1984). The characteristic amphibole in the garnet amphibolite is calcic amphibole, classified in a broad sense as hornblende. These hornblendic amphiboles exhibit medium to high contents of $\mathrm{Al}_{2} \mathrm{O}_{3}$ (maximum $16.05 \%$ ), $\mathrm{Na}_{2} \mathrm{O}$ (maximum $2.32 \%$ ), and $\mathrm{TiO}_{2}$ (maximum $1.18 \%$ ). No significant zoning or chemical variation across the matrix was detected in the amphibole; nor has major chemical variation been found in hornblende close to garnet or in contact with it.

The analyzed plagioclase does not show systematic zoning. It is oligoclase with an anorthite content ranging from $18.78 \mathrm{~mol} \%$ to $23.57 \mathrm{~mol} \%$ and a very low orthoclase end-member (maximum 0.54 mol \%).

Determinations of $P T$ on the peak mineral assemblages in garnet amphibolite have been obtained using the thermometers of Graham and Powell (1984) and Blundy and Holland (1990), and the barometer of Kohn and Spear (1990). The combined application of the methods of Graham and Powell (1984) and Kohn and Spear (1990) to the three investigated samples yields consistent results, with very little dispersion. The $P T$ conditions obtained using garnet cores and the composition of plagioclase and amphibole in the matrix range between $640^{\circ}$ and $680^{\circ} \mathrm{C}$ and 11.1 and 11.9 kbar. Similar $P T$ values were estimated using garnet rims and the same composition of the minerals in the matrix $\left(T=624^{\circ}-677^{\circ} \mathrm{C} ; \quad P=10.5-11.8 \mathrm{kbar}\right)$. The geothermometer of Blundy and Holland (1990) gives similar results, with $660^{\circ}-682^{\circ} \mathrm{C}$ for cores and $663^{\circ}-691^{\circ} \mathrm{C}$ for rims. The relatively high pressures calculated with the geobarometer of Kohn and Spear (1990) have been confirmed using other pressure indicators. This is the case for the $\mathrm{Al}$ content in hornblende (Anderson and Smith 1995), which suggests, for the three samples analyzed, pressures ranging between 9 and $10.7 \mathrm{kbar}$. The thermobarometric conditions calculated for garnet cores (or rims) probably represent a close approximation to the peak metamorphic conditions attained by the garnet amphibolite, as well as an indication of the maximum pressures reached in the ophiolitic unit during the Variscan accretion.

Thrust Geometry and Related Minor Structures. The internal thrusts that repeated the original ophiolitic sequence, superimposing ultramafic on gabbroic rocks, represent old structures of the nappe pile, since they were affected by two systems of crossfolds and developed prior to the extensional detachments (figs. 3, 4). Post-nappe folding provides oblique sections showing the main geometric features of the thrusts and their related shear zones. The Careón thrust superimposed a sheet (minimal dimensions $1 \times 12 \times 18 \mathrm{~km}$ ) onto the Orosa sheet, via a contact roughly parallel to the paleo-Moho. The Vilouriz thrust shows the greatest exposure, and its geometry can be observed along nearly 15 $\mathrm{km}$ parallel to the transport direction and $30 \mathrm{~km}$ along strike. In the north the thrust is arranged parallel to the paleo-Moho exposed in the underlying Careón sheet. In the central section, the Vilouriz sheet descends via two subperpendicular ramps, thereafter resting on the Orosa sheet (figs. $3,4)$. In the southern section, in the Vacariza sector (fig. 3), the Vilouriz sheet consists of an imbricated fan of several minor ultramafic sheets (fig. $4 B)$, while toward the southwest it exhibits a hinterland-dipping duplex geometry (Boyer and Elliot 1982), with the slices dipping toward the north.

Thrust-related shear zones show intensely foliated rocks, locally imbricated, and affected by metric-scale tight isoclinal folds and two systems of shear bands. Minor folds show a constant dextral asymmetry and a variation in the attitude of their axes, which tend to parallelism with the stretching lineation. Close to the thrusts, shear bands $\left(\mathrm{C}^{\prime}\right)$ developed, dragging and surrounding the main $(\mathrm{S}-\mathrm{C})$ foliation and the minor asymmetrical folds. In the 
Table 2. Selected Microprobe Analyses

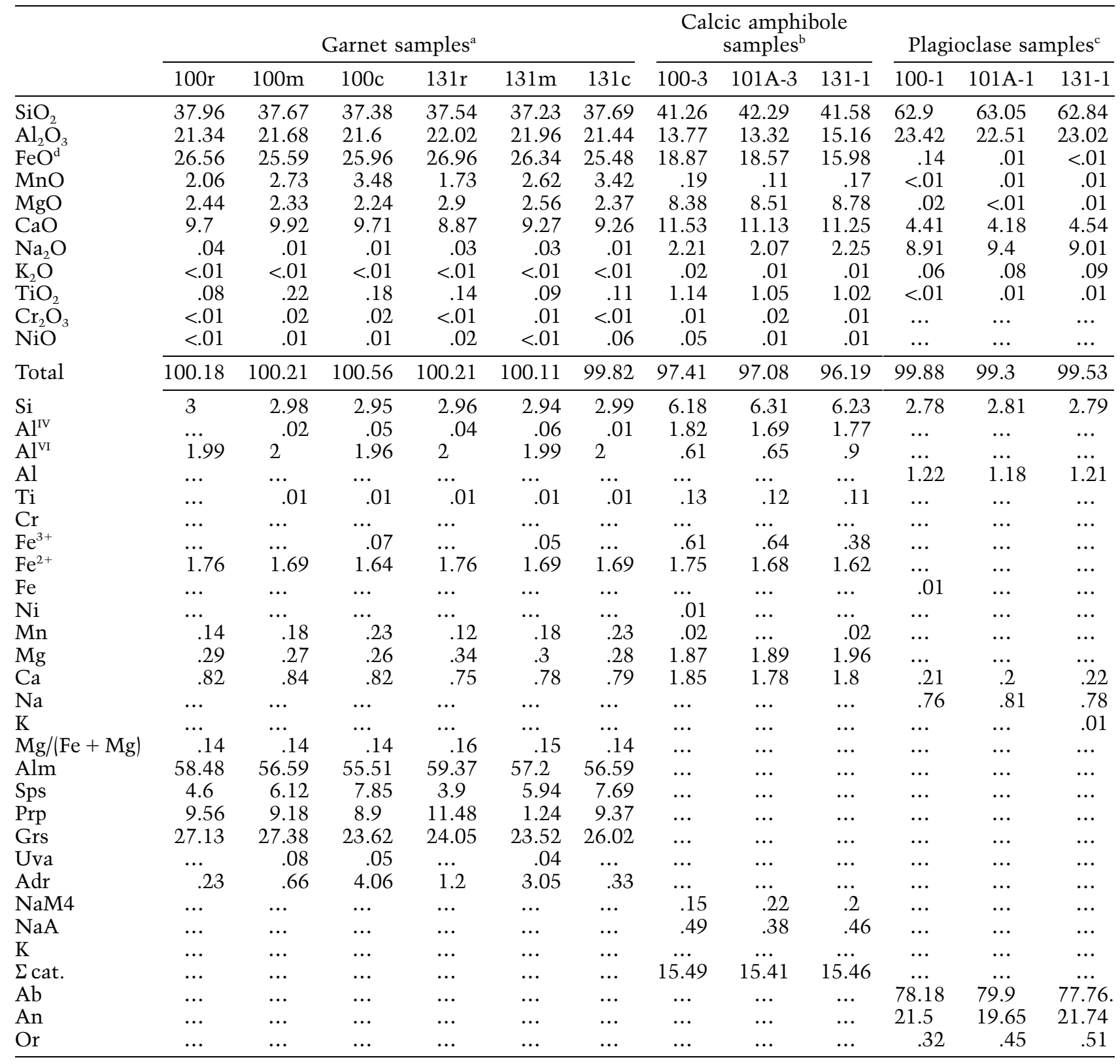

${ }^{\mathrm{a}} \mathrm{r}, \mathrm{rim}$; $\mathrm{m}$, inner zones; c, core.

${ }^{\mathrm{b}}$ Cations on the basis of 23 oxygens, normalized to 13 cations, excluded $\mathrm{Ca}, \mathrm{Na}$, and $\mathrm{K}$.

${ }^{\mathrm{c}}$ Cations on the basis of 8 oxygens.

d Total iron as FeO.

Careón thrust, these $\mathrm{C}^{\prime}$ bands are inclined less steeply than the thrust surface (fig. 7), and the dragging on the S-C planes indicates an emplacement of the upper part toward the east.

Stretching lineation on the foliation planes exhibits a high degree of dispersion throughout the Careón Unit, resulting from small-scale and mapscale subsequent folding. In the northern part, how- ever, where subsequent folding was less intense, a roughly east-west orientation is observed in the Careón and Vilouriz thrusts (fig. 3). This is the case of the lineation marked by recrystallized olivine in the ultramafic rocks, whose foliation developed at the highest temperatures, and also of the lineation in the serpentinite mylonites (figs. 6, 7). Taking into account the attitude of the stretching lineation, 


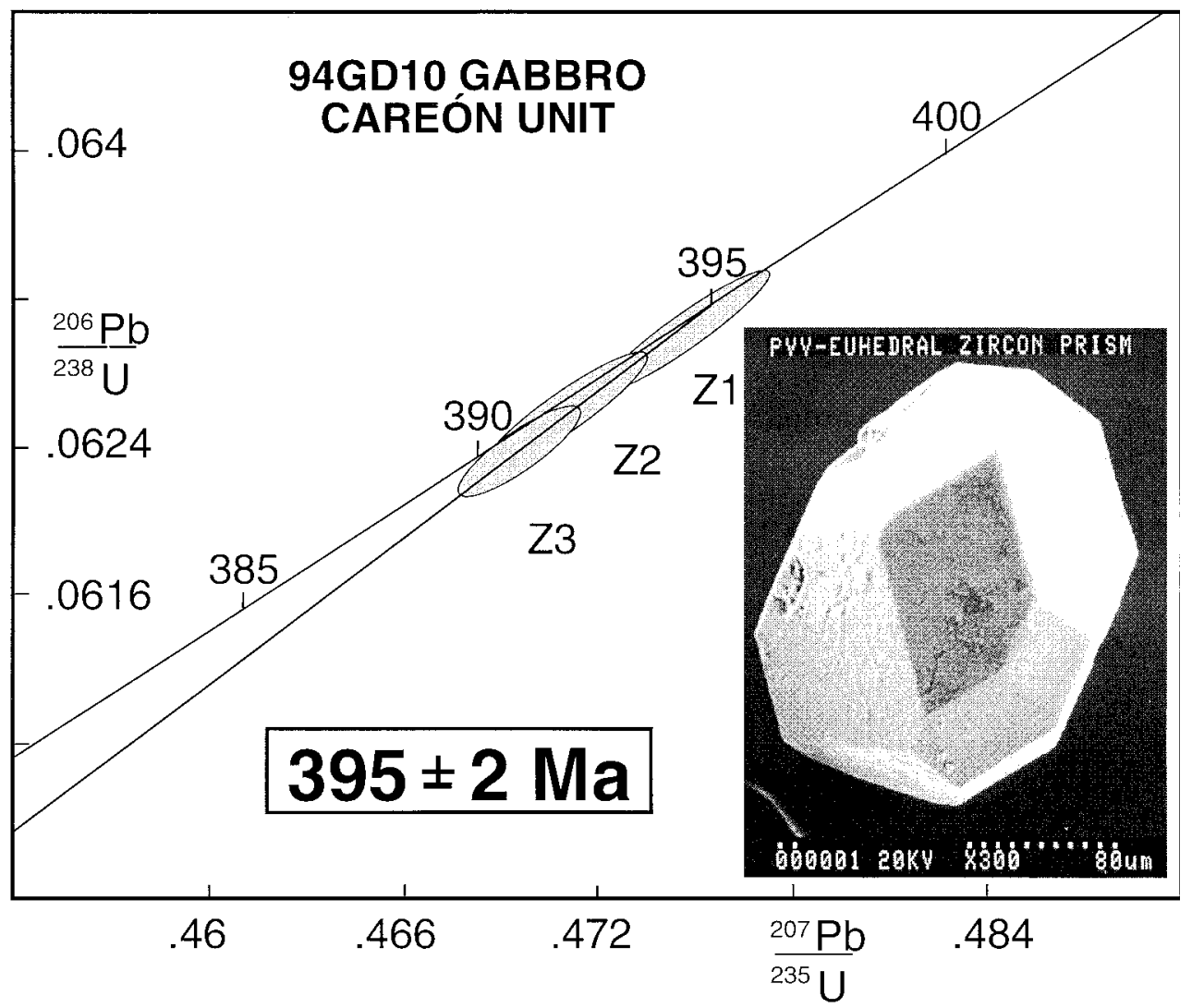

Figure 8. U-Pb concordia diagram for the leucogabbro of the Careón ophiolite and SEM photograph of clear euhedral zircon prism.

fold axes asymmetry, and $\sigma$-type microstructures developed in porphyroclastic amphibolite and shear bands, a consistent top-to-east displacement for the thrust sheets can be inferred.

\section{Tectonic Evolution of the Careón Unit}

The ophiolitic units of northwest Spain and northern Portugal mark the northern Iberian suture, which can be correlated through the Ibero Armorican Arc with the Massif Central suture (Martínez Catalán 1990; Matte 1991).

The Careón Unit is considered a fragment of oceanic lithosphere even though the whole ophiolitic association is not present. The arguments are threefold: (1) Structurally, the unit appears between two terranes of different origins and evolutions (fig. 2): the outer edge of the Gondwana continental margin, represented by the basal units, and an arcrelated terrane, represented by the upper units. (2) With the exception of very scarce and small layers of foliated granitic rocks, emplaced close to the thrust-related shear zones, there is no high-grade gneiss or granulite reminiscent of a continental crust. The possibility that the Careón Unit represents a mafic-ultramafic intrusive complex, formed by underplating of thinned continental crust during a rifting episode, cannot be ruled out, but it is very improbable due to the absence of rocks of continental crust affinity. Moreover, the presence of diabase dikes and the intense hydrothermal metamorphism point to an oceanic setting. (3) The underlying Vila de Cruces Unit (figs. 1, 2, 3), though thoroughly mylonitized, includes pelitic rocks, chert and metabasalt, ultramafic rocks, and, probably, metagabbro. Structurally equivalent in position, the Moeche Unit depicts the whole ophiolitic association, together with an olivine-tholeiitic geochemistry (Arenas 1988). Even if the association is not complete in the Careón Unit, the existence of adjacent ophiolites seems assured, supporting the interpretation that the unit also it represents an oceanic domain.

The Careón Unit has specific characteristics when compared to more common ophiolites. Thus, the upper harzburgite and dunite are serpentinized 


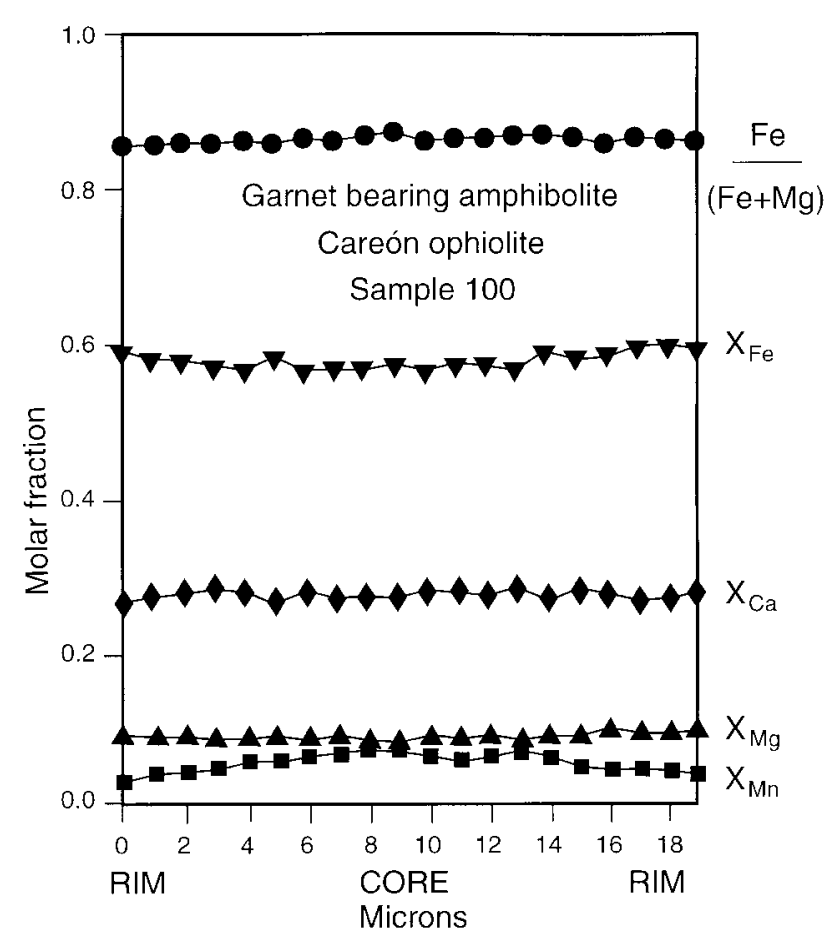

Figure 9. Compositional profiles of a garnet in amphibolite of the Careón Unit (sample 100).

and invaded by diabase and coarse-grained gabbros, and the thin plutonic section is nearly devoid of layered gabbro. These features hamper its assignment to either the harzburgite ophiolite type (HOT) or lherzolite ophiolite type (LOT) of Nicolas (1989). However, it shares some features with an intermediate ophiolite type of which the Xigaze (exposed along the Indus-Zangbo Himalayan suture) would be an example (Girardeau et al. 1985). The Careón Unit can be correlated with the basal part of an ophiolitic sequence with a complex intrusion network that seems to be the product of superimposed magmatic events more than the result of fractional crystallization in a huge magma chamber. It may not have been formed in a midocean ridge, but it might represent a suprasubduction-zone ophiolite formed either in a backarc setting or in the forearc of an active subduction zone. The calc-alkaline affinities of several analyses in the Bazar and Careón Units would support this assertion. The U-Pb age of $395 \pm 2 \mathrm{Ma}$ obtained in the gabbroic section indicates that oceanic crust was being formed by the Early Devonian, when convergence between the upper, arc-derived units and Gondwana was going on (Martínez Catalán et al. 1997, 1999).

The internal structure of the Careón Unit resem- bles a thrust system of the imbricate fan type, with associated minor duplexes and with a shallow detachment level (100-500 m below the paleo-Moho). A staircase geometry, ascending in the transport direction, has been recognized for the Vilouriz sheet, and this, together with the kinematic criteria (east-directed emplacement), leads us to consider these thrusts as synthetic with the subduction polarity toward the west, deduced from the general vergence of the major structures and from the metamorphic gradient of the early high-pressure event in the basal units (Martínez Catalán et al. 1996).

Simultaneous with thrusting, inverted thermal gradients developed. Microstructural variations in the ultramafic allochthonous sheets point to decreasing temperature conditions during increasing deformation. Fine-grained porphyroclastic microstructures, preserved in the upper part of the thrustrelated shear zones, suggest earlier stages of deformation at temperatures in excess of $750^{\circ} \mathrm{C}$, considered the lowest limit of olivine plasticity in the presence of water (Nicolas and Poirier 1976). The development of serpentinite mylonites during the last stages of thrusting, close to the thrust contacts, would occur at temperatures below $550^{\circ} \mathrm{C}$ (upper limit for serpentinization in the presence of water; Moody 1976). Below the allochthonous ultramafic rocks, amphibolite soles developed within individual sheets. They are characterized by a sharp decrease of metamorphic grade downward, from garnet amphibolite $\left(T \approx 650^{\circ} \mathrm{C} ; P \approx 11.5 \mathrm{kbar}\right)$ close to the thrust plane, to epidote-amphibolite facies rocks below. Moreover, some dikes intruding the mantle section did not reach amphibolite facies conditions and exhibit chilled margins. We conclude that some magmatic activity coexisted with the earlier stages of thrusting.

Taking into account the above-mentioned characteristics and the geological setting of the units situated above and below, the emplacement of the Careón Unit will be discussed in the light of two well-known examples of ophiolites with different emplacement histories: obduction and subduction.

Among other distinctive features, ophiolites thrust over unmetamorphosed sequences of passive continental margins (Moores 1982), of which Oman is a representative example (Nicolas 1989), and show the development of a sole with an inverted metamorphic gradient situated below a peridotite mylonite, which records temperatures of deformation $>700^{\circ} \mathrm{C}$. Several features, such as the short time elapsed between oceanic crust generation and development of thrust-related metamorphic soles, the existence of dikes intruding the mantle section, and the subduction-related geochemical affinities 

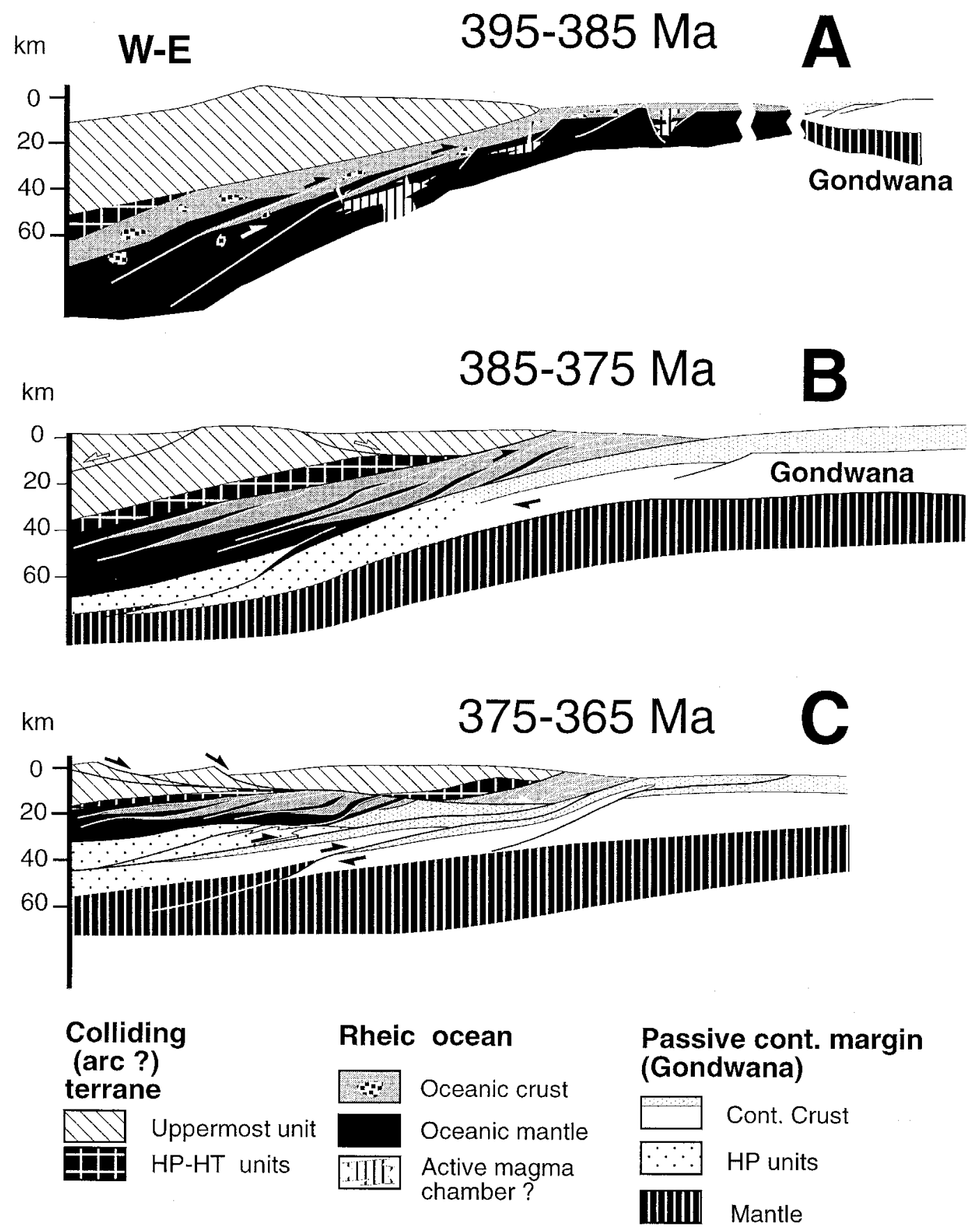

Figure 10. Evolutionary model of the Careón Unit. Subduction of oceanic lithosphere beneath an accretionary wedge induced the stacking of the ophiolitic sheets $(A)$, some of which developed metamorphic soles. Subsequent subduction of the continental crust of Gondwana $(B)$ and its progressive understacking $(C)$ provoked the thinning and tapering of the orogenic wedge through the activity of normal detachments. 
of some components, are explained by the initiation of intraoceanic thrusting near the ridge (Michard et al. 1991; Hacker and Gnos 1997).

In Cordilleran-type ophiolites (Moores 1982), emplacement may involve underthrusting beneath the passive margin rather than overthrusting, as is the case for the Josephine ophiolite (Harper et al. 1994). There, serpentinite mylonites occur at the base of the ophiolite, which is intruded by abundant syntectonic calcalkaline dikes and small plutons supplied by a hot island arc complex being underthrust beneath the ophiolite. A different type of metamorphic (amphibolitic) sole was developed below the ophiolite, without an inverted metamorphic gradient (Harper et al. 1996).

The ophiolitic units of northwest Spain were finally emplaced onto a passive continental margin, represented by the basal units (figs. 1, 2). However, this was not unmetamorphosed, but the outer edge of the passive margin of Gondwana, subducted at the onset of collision. Moreover, subduction of the continental crust occurred later than imbrication of ophiolitic units, according to isotopic dating (see next paragraph), and the minimum pressure attained by the continental rocks, 14-15 kbar (Arenas et al. 1995), was greater than maximum pressure of the Careón ophiolite, 11-12 kbar. Actually, the contact between the Careón Unit and the basal units is a postimbrication extensional detachment (Martínez Catalán et al. 1996). The emplacement of the Careón ophiolite is not a case of obduction over a passive margin.

On the contrary, a subductive emplacement seems granted by the pressures attained during the thrusting event, which suggests a deep environment for the generation of the metamorphic soles. The isotopic ages obtained in the different allochthonous complexes point to a progressive incorporation of the different allochthonous units to an accretionary wedge developed at the Laurentian active margin, as proposed by Martínez Catalán et al. (1997, 1999). The HP-HT (high-pressure-hightemperature) upper units (see characteristics in fig. 2) experienced the first Variscan episode during the Early Devonian, as reported by U-Pb analyses on zircons $(392 \pm 4 \mathrm{Ma}$, Peucat et al. 1990; $406 \pm 4$ Ma, Santos Zalduegui et al. 1996) and on brown titanite (389 $\pm 2 \mathrm{Ma}$, Santos Zalduegui et al. 1996). These units underwent a decompressive amphibolite facies episode during their emplacement onto the ophiolitic units (fig. 10A). Synchronous amphibolite facies metamorphism was retrogressive in the HP-HT upper units $(385.8 \pm 1.5$ and $389.1 \pm$ $2.0 \mathrm{Ma}$, by ${ }^{40} \mathrm{Ar} /{ }^{39} \mathrm{Ar}$ method in hornblende concentrates from retrogranulite rocks; Dallmeyer et al. 1991) and prograde in the underlying ophiolitic unit $\left(389.1 \pm 3.1\right.$ and $383.7 \pm 2.3 \mathrm{Ma},{ }^{40} \mathrm{Ar} /{ }^{39} \mathrm{Ar}$ method, hornblende concentrates from metagabbros and amphibolites; Dallmeyer et al. 1991), indicating an Early to Middle Devonian age for the stacking of the oceanic slices.

The thrust geometry, metamorphic soles, and PT conditions of metamorphism can be explained by a convergent plate boundary, where the oceanic crust was being incorporated by imbrication to a subduction complex, developing thin tectonic slivers of kilometric dimensions (fig. 10A, B). The low grade of metamorphism fits a subduction environment, when taking into account that the pressures were relatively high, as shown by geobarometry. The high temperature found in the metamorphic soles can be understood by the short time that elapsed between the generation of the oceanic crust and its imbrication. The heat was residual in the young oceanic mantle, which justifies the porphyroclastic microstructures developed in the ultramafic sections of the thrust sheets in the early stages of deformation. When thrust over the lower oceanic crust, the hot lithospheric mantle heated it from above, giving rise to the inverted gradients. This process induced, in turn, the cooling and serpentinization of the ultramafic rocks. The attitude of $C^{\prime}$ shear bands indicates that stretching occurred to some extent at the base of the thrust sheets. The ductility of serpentinites may account for the stretching of the ultramafic sections, which were probably thicker when the metamorphic soles were formed than presently. In addition, the proposed setting may explain the intrusion of gabbroic and diabase dikes, arising either from residual subducted and sporadically active magma chambers or from subduction-related magmatism (fig. 10A).

Imbrication of oceanic units was followed by underthrusting of the Gondwana continental margin (fig. 10B), represented by the basal units, where the end of the HP metamorphic event has been dated at $374 \mathrm{Ma}$ (average $\mathrm{Rb}$-Sr ages obtained in posteclogitic phengites by Van Calsteren et al. 1979). The available isotopic data point to synchronism between the unroofing of the HP basal units and the development of extensional detachments in the upper part of the nappe pile. These detachments produced intense retrogression to greenschist facies (dated at $366.8 \pm 0.4$ and $364.4 \pm 0.7 \mathrm{Ma},{ }^{40} \mathrm{Ar} /{ }^{39} \mathrm{Ar}$ method on muscovite concentrate and whole rock analysis in metapelites of the ophiolitic units; Dallmeyer et al. 1997). Rb-Sr ages ranging from 365 to $352 \pm 3 \mathrm{Ma}$ (Santos Zalduegui et al. 1995) in the basal units reflect the progressive exhumation of the subducted outer margin of Gondwana (fig. 10C). 


\section{Conclusions}

The Careón Unit represents a piece of the northern suture in the Iberian Variscan belt, and its study provides information on the evolution of the Rheic ocean, revealing new data concerning early subduction processes that predated the collision tectonics.

The most complete ophiolitic association consists of a mantle section composed of harzburgite and dunite, above which lies a crustal section formed by numerous small intrusions of coarsegrained and pegmatoid gabbros. The whole complex has been intruded by a great number of gabbroic dikes, pegmatoid gabbros, and diabase dikes.

The unit can be correlated with the basal part of an ophiolitic sequence because it seals a suture between the outer edge of Gondwana and an arcderived terrane; it is spatially associated with other ophiolitic units, and rocks of continental signature are absent. The unit seems the product of superimposed magmatic events rather than the result of fractional crystallization in a magma chamber. It may not have been formed in a mid-ocean ridge, but in a suprasubduction zone setting. The U-Pb age of $395 \pm 2 \mathrm{Ma}$ indicates that oceanic crust was still being formed by the Early Devonian, a time when early Variscan convergence had been initiated.

Convergence affected the ophiolites soon after, giving rise to a mantle-rooted thrust system, syn- thetic with the westward polarity of the Variscan subduction of the underlying Gondwana margin. In the ultramafic sheets, a progressive mylonitization, operating under decreasing temperature conditions, produced a peridotite mylonitization, followed by serpentinite mylonitization. Metamorphic soles were developed at the footwall of some sheets and are characterized by a sharp decrease of metamorphic gradient downward, from garnet amphibolite to epidote-amphibolite facies. Corundum-rich metabasic rocks have been observed locally and attest to heat transfer from the overriding ultramafic sheet.

Thermobarometric estimations at a metamorphic sole $\left(T \approx 650^{\circ} \mathrm{C} ; P \approx 11.5 \mathrm{kbar}\right)$ point to a subduction environment for ophiolite emplacement, demonstrating that metamorphic soles with inverted gradients may develop in deep-seated imbrications of young oceanic lithosphere, in subduction complexes.

\section{A C K N O W LE D G M E N T S}

This study has been funded by the DGICYT /Committee of Science and Technology of the Spanish Ministry of Education and Science) and forms part of projects PB-94-1396-C02 and PB97-0234-C02. Constructive review by Y. Dilek and an anonymous referee are kindly acknowledged. Technical assistance with the geochronology was provided by $\mathrm{R}$. Hicks.

\section{REFERE N C E S C I T E D}

Abati, J.; Dunning, G. R.; Arenas, R.; Díaz García, F.; González Cuadra, P.; and Martínez Catalán, J. R. 1999. Early Ordovician orogenic event in Galicia NW Spain: evidence from $\mathrm{U}-\mathrm{Pb}$ ages in the uppermost unit of the Ordenes complex. Earth Planet. Sci. Lett. 165: 213-228.

Anderson, J. L., and Smith, D. R. 1995. The effects of temperature and $\mathrm{fO}_{2}$ on the Al-in-hornblende barometer. Am. Mineral. 80:549-559.

Arenas, R. 1988. Evolución petrológica y geoquímica de la unidad alóctona inferior del complejo metamórfico básico-ultrabásico de Cabo Ortegal Unidad de Moeche y del Silúrico paraautóctono, Cadena Hercínica Ibérica NW de España. Corpus Geologicum Gallaeciae 4, $543 \mathrm{p}$.

Arenas, R.; Gil Ibarguchi, J. I.; González Lodeiro, F.; Klein, E.; Martínez Catalán, J. R.; Ortega Girones, E.; Pablo Maciá, J. G.; and Peinado, M. 1986. Tectonostratigraphic units in the complexes with mafic and related rocks of the NW of the Iberian Massif. Hercynica 2: 87-110.
Arenas, R.; Rubio Pascual, F. J.; Díaz García, F.; and Martínez Catalán, J. R. 1995. High-pressure microinclusions and development of an inverted metamorphic gradient in the Santiago Schists, Ordenes Complex, NW Iberian Massif, Spain: evidence of subduction and syn-collisional decompression. J. Metamorph. Geol. 13:141-164.

Bernard Griffiths, J.; Peucat, J.; Cornichet, J.; Iglesias Ponce de León, M.; and Gil Ibarguchi, J. I. 1985. U$\mathrm{Pb}, \mathrm{Nd}$ isotope and REE geochemistry in eclogites from the Cabo Ortegal Complex, Galicia, Spain: an example of REE immobility conserving MORB-like patterns during high-grade metamorphism. Chem. Geol. 52:217-225.

Blundy, J. D., and Holland, T. J. B. 1990. Calcic amphibole equilibria and a new amphibole-plagioclase geothermometer. Contrib. Mineral. Petrol. 104:208-224.

Bonhommet, N., and Perroud, D. 1986. Apport du paléomagnétisme à la compréhension de l'orogenèse hercynienne en Europe occidentale. Bull. Soc. Geol. France 8:35-42. 
Boyer, S. E., and Elliot, D. 1982. Thrust systems. Am. Assoc. Petrol. Geol. Bull. 66:1196-1230.

Capdevila, R., and Vialette, Y. 1970. Estimation radiometrique de l'age de la deuxième phase tectonique hercynienne en Galice moyenne (NW de 1' Espagne). C. R. Acad. Sci. Paris 270:2527-2530.

Dallmeyer, R. D.; Martínez Catalán, J. R.; Arenas, R.; Gil Ibarguchi, J. I.; Gutiérrez Alonso, G.; Farias, P.; Bastida, F.; and Aller, J. 1997. Diachronous Variscan tectonothermal activity in the NW Iberian Massif: evidence from ${ }^{40} \mathrm{Ar} /{ }^{39} \mathrm{Ar}$ dating of regional fabrics. Tectonophysics 277:307-337.

Dallmeyer, R. D.; Ribeiro, A.; and Marques, F. 1991. Polyphase Variscan emplacement of exotic terranes (Morais and Bragança massifs) onto Iberian successions: evidence from ${ }^{40} \mathrm{Ar} /{ }^{39} \mathrm{Ar}$ mineral ages. Lithos 27: 133-144.

Díaz García, F. 1990. La Geología del sector Occidental del Complejo de Ordenes. Cordillera Hercínica, NW de España. In Nova Terra (3d ed.). Coruña, O Castro, $230 \mathrm{p}$.

Díaz García, F.; Martínez Catalán, J. R.; Arenas, R.; and González Cuadra, P. 1999. Structural and kinematic analysis of the Corredoiras Detachment: evidence for early Variscan synconvergent extension in the Ordenes Complex, NW Spain. Geol. Rundsch., in press.

Dubé, B.; Dunning, G. R.; Lauzière, K; and Roddick, J. C. 1996. New insights into the Appalachian Orogen from geology and geochronology along the Cape Ray fault zone, southwest Newfoundland. Geol. Soc. Am. Bull. 108:101-116.

Frost, B. R., and Tracy, R. J. 1991. P-T paths from zoned garnets: some minimum criteria. Am. J. Sci. 291: 917-939.

Galán, G., and Marcos, A. 1997. Geochemical evolution of high-pressure mafic granulites from the Bacariza formation (Cabo Ortegal Complex, NW Spain): an example of a heterogeneous lower crust. Geol. Rundsch. 86:539-555.

García Garzón, J.; Pablo Maciá, J. G.; and Llamas Borrajo, J. F. 1981. Edades absolutas obtenidas mediante el metodo $\mathrm{Rb} / \mathrm{Sr}$ en dos cuerpos de ortoneises en Galicia Occidental. Bol. Geol. Min. España 92:463-466.

Gebauer, D. 1993. Intra-grain zircon dating within the Iberian Massif: Ollo de Sapo augengneisses, bimodal gneisses from the Massif de Guilleries (Girona), graywacke of the Tentudía Group (serie Negra, SW Spain) and the HP/HT-rock association at Cabo Ortegal (Galicia). XII Reuniao Geol. Oeste Peninsular Univ. Evora 2:41-46.

Gil Ibarguchi, J. I. 1995. Petrology of Jadeite-metagranite and associated orthogneiss from the Malpica-Tuy allochthon (Northwest Spain). Eur. J. Mineral. 7: 403-415.

Girardeau, J.; Mercier, J. C. C.; and Wang Xibing. 1985. Structure of the Xigaze ophiolite, Yarlung Zangbo suture zone, Southern Tibet, China: genetic implications. Tectonics 4:267-288.

Graham, C. M., and Powell, R. 1984. A garnet-hornblende geothermometer: calibration, testing and ap- plication to the Pelona schist, southern California. J. Metamorph. Geol. 2:13-21.

Hacker, B. R., and Gnos, E. 1997. The conundrum of Samail ophiolite: explaining the metamorphic history. Tectonophysics 279:215-226.

Harper, G. D.; Grady, K.; and Coulton, A. J. 1996. Origin of the amphibolite "sole" of the Josephine ophiolite: emplacement of a cold ophiolite over a hot arc. Tectonics 15:296-313.

Harper, G. D.; Saleeby, J. B.; and Heizler, M. 1994. Formation and emplacement of the Josephine ophiolite and the Nevadan orogeny in the Klamath Mountains, California-Oregon: U/Pb zircon and ${ }^{40} \mathrm{Ar} /{ }^{39} \mathrm{Ar}$ geochronology. J. Geophys. Res. 99:4293-4321.

Jamieson, R. A. 1986. P-T paths from high temperature shear zones beneath ophiolites. J. Metamorph. Geol. 4:3-22.

Kohn, M. J., and Spear, F. S. 1990. Two new geobarometers for garnet amphibolites, with applications to southern Vermont. Am. Mineral. 75:89-96.

Kuijper, R. P. 1979. U-Pb systematics and the petrogenetic evolution of infracrustal rocks in the Paleozoic basement of Western Galicia, NW Spain. Verhandeling ZWO Laboratorium Voor Isotopen Geologie 5: $1-101$.

Lancelot, J. R.; Allegret, A.; and Iglesias Ponce de León, M. 1985. Outline of upper Precambrian and Lower Paleozoic evolution of the Iberian Peninsula according to U-Pb dating of zircons. Earth Planet. Sci. Lett. 74: 325-337.

Leake, B. E. 1978. Nomenclature of amphiboles. Am. Mineral. 63:1025-1052.

Lefort, J. P. 1989. Basement correlation across the North Atlantic. Berlin, Springer.

Martínez Catalán, J. R. 1990. A noncylindrical model for the northwest Iberian allochthonous terranes and their equivalents in the Hercynian belt of western Europe. Tectonophysics 179:253-272.

Martínez Catalán, J. R.; Arenas, R.; Díaz García, F.; and Abati, J. 1997. The variscan accretionary complex of NW Iberia: involved terranes and succession of tectonothermal events. Geology 25:1103-1106.

1999. Allochthonous units in the Variscan belt of NW Iberia. In Sinha, A. K., ed. 13th international conference on basement tectonics. Dordrecht, Kluwer, p. 65-84.

Martínez Catalán, J. R.; Arenas, R.; Díaz García, F.; Rubio Pascual, F. J.; Abati, J.; and Marquínez, J. 1996. Variscan exhumation of a subducted Paleozoic continental margin: the basal units of the Ordenes Complex, Galicia, Spain. Tectonics 15:106-121.

Martínez Catalán, J. R.; Klein, E.; Pablo Maciá, J. G.; and González Lodeiro, F. 1984. El complejo de Ordenes Subdivisión, descripción y discusión sobre su origen. Cuad. Lab. Xeol. Laxe 7:139-210.

Matte, P. 1991. Accretionary history and crustal evolution of the Variscan belt in Western Europe. Tectonophysics 196:309-337.

Michard, A.; Boudier, F., and Goffé, B. 1991. Obduction versus subduction and collision in the Oman Case and 
other Tethyan settings. In Peters, T.; Nicolas, A.; and Coleman, R. G., eds. Ophiolite genesis and evolution of the oceanic lithosphere. Boston, Kluwer Academic.

Moody, J. B. 1976. Serpentinization: a review. Lithos 9: 125-138.

Moores, E. M. 1982. Origin and emplacement of ophiolities. Rev. Geophys. Space Physics 20:735-750.

Nicolas, A. 1989. Structures of ophiolites and dynamics of oceanic lithosphere. Boston, Kluwer Academic, 367 p.

Nicolas, A., and Poirier, J. P. 1976. Crystalline plasticity and solid state flow in metamorphic rocks. London, Wiley-Interscience, $444 \mathrm{p}$.

Norrell, G. T.; Teixell, A.; and Harper, G. D. 1989. Microstructure of serpentinite mylonites from the josephine ophiolite and serpentinization in retrogressive shear zones, California. Geol. Soc. Am. Bull. 101: 637-682.

Peucat, J. J.; Bernard-Griffiths, J.; Gil Ibarguchi, J. I.; Dallmeyer, R. D.; Menot, R. P.; Cornichet, J.; and Iglesias Ponce de León, M. 1990. Geochemical and geochronological cross section of the deep Variscan crust: the Cabo Ortegal high-pressure nappe northwest Spain. Tectonophysics 177:263-292.

Priem, H. N. A.; Boelrijk, N. A. I. M.; Verschure, R. H.; Hebeda, E. H.; and Verdurmen, E. A. T. H. 1970. Dating events of acid plutonism through the Paleozoic of the western Iberian Peninsula. Eclogae Geol. Helv. 63: 255-274.

Priem, H. N. A., and Den Tex, E. 1984. Tracing crustal evolution in the NW Iberian Peninsula through the $\mathrm{Rb}-\mathrm{Sr}$ and U-Pb systematics of paleozoic granitoids: a review. Phys. Earth Planet. Int. 35:121-130.

Santos Zalduegui, J. F.; Schärer, U.; and Gil Ibarguchi, J. I. 1995. Isotope constraints on the age and origin of magmatism and metamorphism in the Malpica-Tuy allochthon, Galicia, NW Spain. Chem. Geol. 121: 91-103.

Santos Zalduegui, J. F.; Schärer, U.; Gill Ibarguchi, J. I.; and Girardeau, J. 1996. Origin and evolution of the
Paleozoic Cabo Ortegal ultramafic-mafic complex $\mathrm{NW}$ Spain U-Pb, Rb-Sr and Pb-Pb isotope data. Chem. Geol. 129:281-304.

Schäfer, H. J.; Gebauer, D.; Ibarguchi, J. I.; and Peucat, J. J. 1993. Ion-microprobe U-Pb zircon dating on the $\mathrm{HP} /$ HT Cabo Ortegal Complex Galicia, NW Spain preliminary results. Terra Abstr. 54:22.

Serrano Pinto, M.; Casquet, C.; Ibarrola, E.; Corretge, L. G.; and Portugal Ferreira, M. 1987. Sintese geocronológica dos granitoides do Macizo Hespérico. In Bea, F.; Carnicero, A.; Gonzalo, M.; Lopez-Plaza, M.; and Rodriguez Alonso, M. D., eds. Geología de los granitoides y rocas asociadas del Macizo hespérico. Madrid, Rueda, p. 69-86.

Spear, F. S. 1991. On the interpretation of peak metamorphic temperatures in light of garnet diffusion during cooling. J. Metamorph. Geol. 9:379-388.

Spear, F. S., and Kimball, K. L. 1984. Recamp: a fortran program for estimating $\mathrm{Fe}^{3+}$ contents in amphiboles. Comput. Geosci. 10:317-325.

Stacey, J. S., and Kramers, J. D. 1975. Approximation of terrestrial lead isotope evolution by a two-stage model. Earth Planet. Sci. Lett. 26:207-221.

Suárez, O.; Ruiz, F.; Galán, G.; and Vargas, I. 1978. Edades $\mathrm{Rb}-\mathrm{Sr}$ de granitoides del Occidente de Asturias (NW de España). Trab. Geol. 10:437-442.

Van Calsteren, P. W. C.; Boelrijk, N. A. I. M.; Hebeda, E. H.; Priem, H. N. A.; Tex, E. Den.; Verdurmen, E. A. T. H.; and Verschure, R. H. 1979. Isotopic dating of older elements including the Cabo Ortegal maficultramafic complex in the Hercynian Orogen of NW Spain: manifestation of a presumed early Paleozoic mantle-plume. Chem. Geol. 24:35-56.

Vogel, D. E. 1967. Petrology of an eclogite and pyrigarnite bearing polymetamorphic rock complex at Cabo Ortegal, northwest Spain. Leid. Geol. Meded. 40: 121-213.

Yardley, B. W. D. 1989. An introduction to metamorphic petrology. Essex, Longman Scientific \& Technical, 249 p. 